\title{
Health and Nutrition Issues Affecting Academic Involvement of Adult Learners in Literacy Programmes of Kogi State, Nigeria
}

\author{
Linus Okechukwu Nwabuko ${ }^{1}$, Eberechukwu Charity Eneh $^{1} \&$ Eunice R. Idakpo ${ }^{2}$ \\ ${ }^{1}$ Department of Adult Education and Extra-Mural Studies, University of Nigeria, Nsukka, Nigeria \\ ${ }^{2}$ College of Education Okene, Kogi State, Nigeria \\ Correspondence: Eberechukwu Charity Eneh, Department of Adult Education and Extra-Mural Studies, \\ University of Nigeria, Nsukka, Nigeria. E-mail: eberechukwu.eneh.@unn.edu.ng
}

Received: May 12, 2019 Accepted: June 15, 2019 Online Published: July 28, 2019

doi:10.5539/gjhs.v11n8p128

URL: https://doi.org/10.5539/gjhs.v11n8p128

\begin{abstract}
Objective: This study investigated health and nutrition issues affecting academic involvement of Adult learners in literacy programme in Kogi State, Nigeria. The specific purpose of the study was: to ascertain the extent health and nutrition affect academic involvement of adult learners in literacy programmes in Kogi State Nigeria.
\end{abstract}

Materials and Method: The design for the study was a descriptive survey design. A structured questionnaire was used to collect data which wereanalysed using mean scores and standard deviation while t-test statistic was used to test the hypothesis that guided the study.

Results: Results of the analysis showed among others health and nutrition issues such as chronic illness, poor nutrition and hunger affect academic involvement of adult learners. The results also showed that unhealthy adult learners do not feel happy in class during lessons or learning activities.

Conclusion: Based on the finding, it was concluded that health and nutrition have some level of relationship with adult learners' academic involvement to a high extent.

Keywords: health and nutrition, academic involvement, adult learners, Nigeria

\section{Introduction}

Nutrition has been associated in one way or another with health or illness. In fact, many of the ideas held by people for preventing or curing diseases are based on good nutrition. The satisfactory intake of good food by people is essential for the maintenance of tissue structure and body functions. According to Ahuekire (2003), chronic illnesses arising from prolonged poor diets and nutrition constitute a potential obstacle to academic success. Nutrition and food choices range in quality from healthy and beneficial to poor and potentially harmful categories. The food one chooses to eat today can impact his or her health tomorrow. For instance, the nutrients in fruits, vegetables, fish and nuts help protect your memory. The brain requires sufficient nutrients to function normally. According to Linus (2003), proper nutrition is essential for normal cognition. He stated that a healthy diet that is low in fat and high in essential nutrients reduces the risk of memory loss, helps prevents stroke and boosts alertness.

Furthermore, Bauer (2009) stated that the brain needs a steady supply of glucose or sugar to concentrate and stay alert, and also that a deficiency in iron prevents adequate oxygen delivery to the brain which can cause fatigue and poor mental performance. According to medical science, good nutrition helps ensure a proper supply of blood to the brain, therefore, lowering the risk of a stroke. Bad nutrition, on the other hand, can impair cognitive function. Health has been noted as a primary determinant of school outcomes. Glewave (2002), associated proper nutrition with cognitive development when he stated that poorly fed and unhealthy students do worse in school. According to Tarozzi and Mahajan (2007), unhealthy students do worse in school because they are more likely to be absent from school and have less time and energy for serious academic work. Generally, any student with challenges of ill-health and poor nutrition will definitely have problems concentrating on his or her studies. Health-related factors such as hunger, physical, emotional abuse and chronic illness can lead to poor academic involvement of adult learners in literacy programmes.

In addition, Dunkle and Nash (2011) stated that academic success is an excellent indicator for the overall wellbeing 
of learners and a primary indicator and determinant of adult health. In the same vein, Harper and Lynch (2007), recognized the close relationship between health and education as well as the need to foster the health and wellbeing of the learners within the educational environment. This is relevant to the current study. This is because; the study seeks to investigate nutrition and health as a home environmental factor affecting academic involvement of adult learners in literacy programmes in Kogi State, Nigeria. In the recent past, for instance, programmes that are primarily designed to improve academic involvement are important public health studies. Studies show that there is a strong link between good nutrition and academic involvements. Healthier are better learners. In fact, when students' basic nutritional needs are met, they perform better at school.

Furthermore, there is strong evidence that students whose health care needs are met are less likely to miss school days because of illness and also better able to focus on learning in the classroom, hence poor health adversely affects school success (Roy, 2010). Health differences are noted based on income. It has also been observed that people in households with low income are least likely to report being in very good health (Arturo, 2010). Adequate nutrition in terms of good feeding enhances sound health while sound health has a direct bearing on mental ability. So by inference, an adult learner who enjoys a significantly high intake of good food will consequently enjoy sound health and sound health enhances academic involvement.

Nutrition and health is a home environment factor that may affect academic involvement of adult learners. Linus (2003) stated that nutrition and health are all about the practice of values of health to keep healthy with regards to ourselves and our environment. Hygienic conditions coupled with proper nutrition promote sound mental and physical health of an individual (Emanyi, 2007). According to Martin (2007), health means the condition of one's body especially whether one is ill or not, while nutrition means food considered as something that keeps one healthy. For instance, an adult on good nutrition enjoys healthy living which promotes sound mental development which will, in turn, enhance their academic involvement. On the other hand, poor nutrition makes the adult unhealthy thereby hampering their academic involvement. Consequently, this study sought to investigate health and nutrition issues affecting academic involvement of adult learners in literacy programmes of Kogi State, Nigeria with the objective of investigating the extent health and nutrition affect academic involvement of adult learners in literacy programmes in Kogi State Nigeria.

\section{Materials and Method}

The design that was adopted in this study is a descriptive survey research design. According to Omede and Odiba (2009), survey design is a descriptive study that attempts to identify, explain or compare events in their settings. This design was used because the study merely sought information from the respondents as the situation exists without any form of manipulation.

This study was carried out in Kogi, State Nigeria. Kogi State is bordered by the following states. Benue and Nassarawa to the East, Kwara to the West, Federal Capital Territory (FCT) to the North, Edo and Enugu to the South East. Kogi State is divided into three senatorial zones, namely: Kogi East, West and Central. Kogi state is structured into 21 local government areas. It comprises three major ethnic groups, that is, Igala, Ebira and Okun (Yoruba). Education is the State's main social industry. The people take pride in the education of their siblings. Many festivals exist in Kogi state. These include ItaloEgbe, Ibegwu and Ogani among the Igalas, Apanibe fishing festival among the Okun speaking people. The people of Kogi are predominantly farmers in the cultivation of the following; yam, cassava, maize, groundnut etc. The choice of Kogi state for this study was justified by the reported low academic involvement of adult learners in adult literacy programmes in the state (Sani, 2013). This development indicates that some of these home environment in Kogi state. The population of the study consisted of facilitators and adult learners from the 21 Local Government Areas of Kogi State. The population for the study comprised 2,115 facilitators and 3,185 adult learners-making a total of 5,300 respondents.

The sample for this study consisted of 5,300 respondents, comprising 1,053 facilitators and 1593 adult learners in the 21 local government areas of Kogi State. A proportionate Stratified Random Sampling Technique was used to draw the sample from the population. According to Omede and Odiba (2009), stratified sampling is a technique of sampling procedure. The technique divides the population into homogenous sub-groups containing members who share common characteristics. Continuing the authors stated that in this type of sampling procedure, each member of the target population has an equal and independent chance of being included in the sample. Independence in this sense implies that the selection of an element does not in any way affect the selection of the other elements of the population. The sample for this study consisted of 2,6246 respondents, comprising 1,053 facilitators and 1593 adult learners in the 21 Local Government Areas of Kogi State. The choice of these respondents was as a result of their involvement in adult literacy programmes. About $50 \%$ of facilitators and adult learners will be randomly drawn from the entire population to ensure average representativeness. Hence, the sample size was 2,646. This 
sampling technique is in agreement with the recommendation of Waifor (2001) that at most $50 \%$ rating procedure was adopted, because, it aims at ensuring proportionate representation of these sub-groups in the sample.

The instrument that was used in this study is a questionnaire. It was designed by the researchers based on the purpose of the study. The instrument is made up of two sections, 'A' and 'B'. Section 'A' elicited information on the bio-data of the respondents while ' $\mathrm{B}$ ' elicited information on the extent to which nutrition and health affect the academic involvement of adult learners in literacy programmes in Kogi State. A total of 5 items were used. The respondents rated the items on a 4-point Rating Scale of very High Extent (VHE =4 Points), High Extent (HE = 3 Points) Low Extent $(\mathrm{LE}=2$ Points $)$ and very Low Extent $(\mathrm{VLE}=\mathrm{I}$ Point $)$.

The validity of the instrument was established by giving it to three experts, two from the Department of Adult Education and Extra-Mural Studies, and one from Measurement and Evaluation. These experts assessed the questionnaire items on the basis of clarity of the statements, relevance of the content and suitability of rating scale adopted. The corrections and suggestions made by these experts were effected and inserted in the final draft of the questionnaire.

In order to determine the reliability of the instrument, a trial-testing was done by administering the questionnaire to 50 adult education facilitators and adult learners from two local government areas-Gboko and Oturkpo of Benue State that were not involved in the study. The choice of this location is because they possess similar characteristics with the target population in terms of their involvement in adult literacy programmes, agricultural practices, cultured and value system.

The reliability of the instrument was estimated in terms of internal consistency using Cronbach alpha. The reliability coefficient obtained for the instrument was 0.945 . This is a pointer to the fact that the instrument is very reliable. The researchers with the aid of seven trained research assistants on data collection administered 2,646 copies of the instrument to the respondents; (facilitators) during their monthly meetings and (adult learners) during their literacy learning sections in the literacy centres concerned. The administered instrument was collected on the spot. The data for this study were subjected to statistical analysis using means, standard deviation and t-test is to be used to test the hypothesis at $0.05 \%$ level of significance. A criterion mean of 2.5 and above were accepted while those below 2.5 were rejected.

\section{Results}

\subsection{Research Question}

To what extent do health and nutrition affect academic involvement of adult learners in literacy programmes in Kogi State?

Table 1. Mean and standard deviation ratings of facilitators and adult learners on the extent to which nutrition and health affect academic involvement of adult learners in literacy programmes in Kogi State

\begin{tabular}{|c|c|c|c|c|c|c|c|}
\hline \multirow[t]{2}{*}{$\mathbf{s} / \mathbf{n}$} & \multirow[t]{2}{*}{ Items } & \multirow{2}{*}{$\begin{array}{l}\text { Facilitators } \\
\text { Mean }\end{array}$} & \multicolumn{3}{|c|}{$\begin{array}{l}\text { Adult } \\
\text { Learners }(N=1593)\end{array}$} & \multirow[b]{2}{*}{$\mathrm{SD}$} & \multirow[b]{2}{*}{ Rem } \\
\hline & & & SD & Rem & Mean & & \\
\hline 1 & Chronic illness constitutes an obstacle to adult learning activities & 3.62 & 0.56 & $\mathrm{HE}$ & 3.71 & 0.47 & $\mathrm{HE}$ \\
\hline 2 & $\begin{array}{l}\text { Good health is the primary determinant of excellent academic } \\
\text { involvement of adult learners. }\end{array}$ & 3.39 & 0.80 & $\mathrm{HE}$ & 3.42 & 0.83 & $\mathrm{HE}$ \\
\hline 3 & $\begin{array}{l}\text { Unhealthy adult learners do not feel happy in class during lesson } \\
\text { or learning activities }\end{array}$ & 3.68 & 0.56 & $\mathrm{HE}$ & 3.78 & 0.43 & $\mathrm{HE}$ \\
\hline 4 & Poor nutrition obstructs sound academic work of adult learners. & 3.66 & 0.59 & $\mathrm{HE}$ & 3.67 & 0.61 & $\mathrm{HE}$ \\
\hline 5 & Hunger limits academic involvement of the adult learner & 3.36 & 0.54 & $\mathrm{HE}$ & 3.43 & 0.49 & $\mathrm{HE}$ \\
\hline
\end{tabular}

NB: NS = Not Significant; $t=t$-test calculated; $d f=$ Degree of Freedom; and $N=$ Number of Respondents, $S D=$ standard deviation.

Table 1 reveals that both facilitators and adult learners rated the items above 2.5 mean benchmark. This means that they accepted at a high extent that health and nutrition affect academic involvement of adult learners in literacy programmes. Hence, chronic illness constitutes an obstacle to adult learning activities; good health is a primary 
determinant of excellent academic involvement of adult learners; unhealthy adult learners do not feel happy in class during lessons or learning activities; poor nutrition obstructs sound academic work of adult learners, and hunger limits academic involvement of adult learners.

\subsection{Hypothesis}

There is no significant difference between the mean ratings of facilitators and adult learners on how health and nutrition affect academic involvement of adult learners in adult literacy programmes in Kogi State.

Table 2. T-test of independent showing mean and standard deviation ratings of facilitators and adult learners on health and nutrition affect academic involvement of adult learners in adult literacy programmes in Kogi State

\begin{tabular}{lllllllll}
\hline & Grouping & N & Mean & Std. deviation & t & df & Sig. (2- tailed) & Decision \\
\hline \multirow{2}{*}{ Overall } & Facilitators & 1053 & 3.54 & 0.41 & -1.08 & 2644 & 0.47 & NS \\
& Adult learners & 1593 & 3.60 & 0.35 & & & & \\
\hline
\end{tabular}

NB: NS = Not Significant; $\mathrm{t}=\mathrm{t}$-test calculated; $\mathrm{df}=$ Degree of Freedom; and $\mathrm{N}=$ Number of Respondents.

Table 2 reveals that the calculated value of $\mathrm{t}(-1.08)$ has a probability value $(0.47)$ which is greater than the 0.05 level of significance. Therefore, the hypothesis that there is no significant difference between the mean ratings of facilitators and adult learners on how health and nutrition affect academic involvement of adult learners in adult literacy programmes in Kogi State was upheld.

\section{Discussion}

The findings revealed that both facilitators and adult learners accepted at a high extent that nutrition and health affect academic involvement of adult learners in literacy programmes. Issues such as chronic illness, poor nutrition and hunger were taken to a high extent as factors that obstruct learning activities. It was found that there is no significant difference between the mean ratings of the responses of facilitators and adult learners on how health and nutrition affect academic involvement of adult learners in adult literacy programmes in Kogi state, Nigeria. This is in line with Manglakayise (2007) and Marjoribanks (2009) who emphasized that nutrition and health are one of the major boosters of academic involvement. To these authors, hunger especially causes emotional destabilization which does not allow for concentration on academic work. Arguably adequate nutrition in terms of good feeding enhances sound health while sound heath has direct bearing on mental ability. This agrees with our hypothesis which states that there is no significant difference between the mean ratings of facilitators and adult learners on how nutrition and health affect academic involvement of adult learners in literacy programmes. Hence, adult learners who enjoy a significantly high intake of good food will consequently enjoy sound health which enhances academic involvement.

\section{Conclusion}

The study was carried out to ascertain health and nutrition affecting academic involvement of adult learners in literacy programmes in Kogi State. The following conclusion was drawn based on the findings of the study. The study stressed that health and nutrition have some level of relationship with adult learners' academic involvement. According to the findings of this study, health and nutrition affect adult learners' academic involvement to a high extent. Finally, there is no significant difference between the mean ratings of the responses of facilitators and adult learners on how health and nutrition affect academic involvement of adult learners in adult literacy programmes in Kogi state, Nigeria.

\section{Competing Interests Statement}

The authors declare that there are no competing or potential conflicts of interest.

\section{References}

Ahuekire, O. (2003). Advanced Nutrition and Diet Therapy. Ibadan: University.

Arturo, E. (2010). Parents and Teachers. London: Nelson Publishing Company.

Baurer, J. (2009). Dietary preference among adults: Issue of Nutrition. New York: NBC Publishers.

David, C. N. (2007). Effects of family size and academic achievement. Ilorin: Success Education Services.

Dunkle, M. C., \& Nash, N. A. (2011). Beyond the Health Room. Resource Centre on Educational Equity, 8(8), 124-143. 
Emanyi, L. (2007). Social Environment as it affect Adult Learning process (Unpublished M.Ed. Thesis, University of Botswana).

Glewave, B. (2002).Health, nutrition and mental soundness. Turkey: Light Printers Ltd.

Harper, S., \& Lynch, I. (2007). Trend in socio-economic inequalities in adult healthbehaviours among adolescents, youths and adults. Public Health Reports, 12(2), 177-189. https://doi.org/10.1177/003335490712200207

Hayer, A. E. (2006). Birth order and college attendance. Journal of Marriage and the Family, 28(6), 133-142.

Hill, N. E. (2004). Effects of parental socio-economic status on academic performance. Journal of Child Development, 75(5), 149-159.

Johnson, G. O. (2003). Education for slow learners. Englewood; Cliffs Printers

Lamb, M. E. (2001). Association between parental agreement in rearing and the characteristics of families. International Journal of Behavioural Development, 12(3), 205-210

Lamb, M. E. (2001). Association between parental structure and learning. International Journal of Behavioural Development, 12(2), 115-129.

Linus, P. (2003). Micronutrient and cognitive function. New York: NBC Publishers

Manglakayise, G. M. (2007). Home environment and pupils academic Achievement (Dissertation Submitted to the Department of Education, University of Zulu land, South Africa).

Marjoribanks, K. (2007).Gender, social class, family environment and adolescence aspirations.Australia Journal of Education, 31(9), 43-54. https://doi.org/10.1177/000494418703100103

Matin, S. (2007).Macmillan English dictionary for advance learners. London: Macmillan publishers.

Omede, J., \& Odiba, P. (2009). Essentials of Educational Research. Lagos: Sam Artrade.

Roy, G. N. (2010).Chronic illness and school performance. Journal of Children's Health Foundation, 10(1), $72-84$.

Sani, O. (2013). Adult, youth illiteracy level in kogi state. Retrieved from http://www.kogireport.com /adult-youth-iliteracy-level-in-kogi-at-56/

Tarozzi, J., \& Mahaja, P. (2007). Housing and health. American Journals of Public Health, 45(1), 60-74.

\section{Copyrights}

Copyright for this article is retained by the author(s), with first publication rights granted to the journal.

This is an open-access article distributed under the terms and conditions of the Creative Commons Attribution license (http://creativecommons.org/licenses/by/4.0/). 